\title{
Using field-evolved resistance to Cry1F maize in a lepidopteran pest to demonstrate no adverse effects of Cry1F on one of its major predators
}

\author{
Jun-Ce Tian • Hilda L. Collins · Jörg Romeis • \\ Steven E. Naranjo • Richard L. Hellmich • \\ Anthony M. Shelton
}

Received: 13 December 2011/Accepted: 19 February 2012/Published online: 29 February 2012

(C) The Author(s) 2012. This article is published with open access at Springerlink.com

\begin{abstract}
Spodoptera frugiperda (JE Smith) represents the first documented case of field-evolved resistance to a genetically engineered crop expressing an insecticidal protein from Bacillus thuringiensis (Bt). In this case it was Cry1F-expressing maize (Mycogen 2A517). The ladybird beetle, Coleomegilla maculata, is a common and abundant predator that suppresses pest populations in maize and many other cropping systems. Its larvae and adults are polyphagous, feeding on aphids, thrips, lepidopteran eggs and larvae, as well as plant tissues. Thus, C. maculata may be exposed to $\mathrm{Bt}$ proteins expressed in genetically engineered crops by several pathways. Using Cry1Fresistant $S$. frugiperda larvae as prey, we evaluated the
\end{abstract}

J.-C. Tian · H. L. Collins · A. M. Shelton ( $ه)$ Department of Entomology, Cornell University/New York State Agricultural Experiment Station (NYSAES), 630

West North Street, Geneva, NY 14456, USA

e-mail: ams5@cornell.edu

J. Romeis

Agroscope Reckenholz-Tänikon Research Station ART,

Reckenholzstr. 191, 8046 Zurich, Switzerland

S. E. Naranjo

USDA-ARS, Arid Land Agricultural Research Center,

21881 North Cardon Lane, Maricopa, AZ 85138, USA

R. L. Hellmich

Department of Entomology, USDA-ARS, Corn

Insects and Crop Genetics Research Unit, Iowa State

University, 110 Genetics Laboratory c/o Insectary,

Ames, IA 50011, USA potential impact of Cry1F-expressing maize on several fitness parameters of $C$. maculata over two generations. Using Cry1F resistant prey removed any potential prey-mediated effects. Duration of larval and pupal stages, adult weight and female fecundity of C. maculata were not different when they were fed resistant $S$. frugiperda larvae reared on either Bt or control maize leaves during both generations. ELISA and insect-sensitive bioassays showed $C$. maculata were exposed to bioactive Cry1F protein. The insecticidal protein had no effect on $C$. maculata larvae, even though larvae contained 20-32 ng of Cry $1 F / g$ by fresh weight. Over all, our results demonstrated that the Cry1F protein did not affect important fitness parameters of one of $S$. frugiperda's major predators and that Cry $1 \mathrm{~F}$ protein did not accumulate but was strongly diluted when transferred during trophic interactions.

Keywords Cry $1 \mathrm{~F} \cdot$ Biosafety $\cdot$ Coleomegilla maculata $\cdot$ Spodoptera frugiperda

\section{Introduction}

Maize, Zea mays L., is one of the most important world crops with over 150 million hectares planted in 2009 (FAOSTAT 2009). Because many important pests of maize are lepidopterans, transgenic maize expressing insecticidal proteins (Cry toxins) from Bacillus thuringiensis (Bt maize) has been 
commercially grown in the United States and globally since 1996. Bt maize has been adopted to control a series of stalk, whorl, leaf and ear infesting Lepidoptera (Hellmich et al. 2008) and globally was planted in 16 countries on a total of 39 million hectares in 2010 (James 2010). Although Bt crops have been planted for 15 years and the vast majority of published reports have shown no negative effects of $\mathrm{Bt}$ crops on nontarget organisms (Romeis et al. 2006; Marvier et al. 2007; Wolfenbarger et al. 2008; Naranjo 2009), the ecological safety of Bt plants continues to be debated. Much of this debate has focused non-target beneficial species (predators and parasitoids) and on whether any purported negative effects are in fact due to the $\mathrm{Bt}$ protein or quality of the host or prey on which the natural enemy feeds (Shelton et al. 2009a).

The fall armyworm (FAW), Spodoptera frugiperda (J. E. Smith) (Lepidoptera: Noctuidae), is an agricultural pest of tropical-subtropical origin in the Western Hemisphere. Its larvae feed on more then 60 plant species; however, maize, peanuts, rice, cotton and sorghum are favored (Luginbill 1928). FAW often infest whorl stage maize where it can substantially reduce plant growth, but the insect also infests ears where it can cause considerable damage. Although estimates of damage are difficult to assess, in the late 1970 s losses in Georgia alone were estimated at $\$ 137$ million (Sparks 1979). Insecticidal control to prevent injury in field maize is difficult and generally not cost effective. The first Bt-maize plants grown in the United States expressed Cry1 Ab proteins that were primarily targeted against the European corn borer, Ostrinia nubilalis (Hübner) (Leidoptera: Crambidae) but were less effective against FAW. In 2001, Herculex $I^{\circledR}$ (Cry1F) maize was approved in the United States and targeted both $O$. nubilalis and FAW (Hellmich et al. 2008). Reports indicated that it could substantially reduce losses by FAW (Buntin et al. 2004; Buntin 2008; Siebert et al. 2008). However, FAW resistance to Herculex $I^{\circledR}$ maize was documented in Puerto Rico by 2006, only 3 years after its commercialization (Matten et al. 2008; Tabashnik et al. 2009; Storer et al. 2010). The high levels of field damage combined with a high laboratory-derived resistance ratio made FAW resistance the first welldocumented case of field-evolved resistance to $\mathrm{Bt}$ plants. This resistance also afforded us an opportunity to use it for studies on tritrophic interactions with natural enemies of FAW.
One major ecological concern regarding the biosafety of Bt crops on the environment is their potential effects on non-target organisms (NTO), especially predators and parasitoids that play an important role in pest control (Romeis et al. 2006; Kennedy 2008; Romeis et al. 2008). The ladybird beetle Coleomegilla maculata (DeGeer) (Coleoptera: Coccinellidae) is a common and abundant predator that suppresses pest populations in maize and many cropping systems. Its larvae and adults are polyphagous, feeding on aphids, thrips, lepidopteran eggs and larvae, as well as plant tissues. Thus, C. maculata may be exposed by several pathways to insecticidal proteins expressed in $\mathrm{Bt}$ crops. Because C. maculata is an important biological control agent and suitable for laboratory experiments, it is commonly used to evaluate the risks of Bt crops.

In research conducted on the potential effects of $\mathrm{Bt}$ maize (expressing Cry3Bb1 or Cry1 Ab) and Bt cotton (expressing Cry2Ab and Cry1Ac) on C. maculata, no direct negative impacts by these $\mathrm{Bt}$ crops have been detected (Pilcher et al. 1997; Duan et al. 2002; Lundgren and Wiedenmann 2002, 2005; Li et al. 2011b). However, none of these studies were conducted with insects that had evolved resistance in the field to a Bt plant. Using Cry1F-resistant FAW from the field would allow one to avoid questions of potential differences in laboratory or field-derived $\mathrm{Bt}$ resistance as well as overcome any potential preymediated effects (Romeis et al. 2011) of Cry1F maize on C. maculata, thus providing additional assurance about its safety to this important predator. The objective of this study was to study the potential effects of Cry1F maize on C. maculata using Cry1Fresistant FAW as prey. Survival, development time, adult weight and female fecundity were evaluated over two generations.

\section{Materials and methods}

Plants

Seeds of Bt maize (Mycogen 2A517), expressing Cry1F protein, and the corresponding non-transformed near isoline (Mycogen 2A496) were obtained from Dow AgroSciences (Indianapolis, IN). Bt maize and non-Bt maize were grown simultaneously in the same green house at Cornell's New York State Agricultural Experiment Station in Geneva, NY. 
Plants were grown in Ray Leach Cone-tainer Cells (diameter $3.8 \mathrm{~cm}$; depth $21 \mathrm{~cm}$; volume $164 \mathrm{ml}$ ) (Stuewe \& Sons, Tangent, OR) at $21 \pm 3^{\circ} \mathrm{C}$ under a light and dark regime of 16:8 h.

Insects

A Cry1F-resistant strain of FAW was obtained from Dow AgroSciences in 2010 and maintained in our laboratory on artificial diet. This strain developed resistance to Cry1F maize in Puerto Rico (Storer et al. 2010) and is able to survive on Cry $1 \mathrm{~F}$ maize.

To detect the bioactivity of Cry1F, we used a susceptible strain of the diamondback moth, Plutella xylostella (Linnaeus) (Lepidoptera: Plutellidae), which has been continuously reared on artificial diet since 1988 (Shelton et al. 1991). Second instar P. xylostella were used for detecting bioactivity of Cry1F, as described below.

Coleomegilla maculata reared on artificial diet ( $\mathrm{Li}$ et al. 2011a) were used in the tests. This colony originated from Pioneer Hi-Bred International, Inc. (Johnston, IA) and was maintained in a climatic chamber at $27 \pm 1{ }^{\circ} \mathrm{C}, 50 \pm 10 \% \mathrm{RH}$, and $16: 8 \mathrm{~h}$ photoperiod. Newly hatched 1 st instar larvae were used.

Expression of Cry1F in maize leaves

When maize reached the V1, V3, V5, V7, V10 and VT stage (Ritchie et al. 1992), three leaf samples were collected from both Bt and non-Bt maize. Each sample was approximately $20 \mathrm{mg}$ and obtained from the second new leaf. All samples were weighed, put into $1.5 \mathrm{ml}$ centrifuge tubes, and stored at $-20^{\circ} \mathrm{C}$ until Cry $1 \mathrm{~F}$ levels were measured.

\section{Bioassay with S. frugiperda}

FAW neonates were individually kept in 30-ml cups and fed leaves of Bt maize or non-Bt maize at the 5-8 leaf stage. There were 30 replications for both treatments. Leaves were changed daily and larvae checked daily until death or pupation. The number of days until pupation or death was recorded. After FAW reached pupation, pupal weight was recorded. The longevity of adults, not provided with any nourishment, also was recorded.
Tri-trophic bioassay with $C$. maculata

First instar C. maculata were individually kept in 30-ml cups and supplied with either 1st or 2nd instar FAW fed Cry1F maize (V5) or control maize (V5). A piece of control maize leaf was placed in each cup to eliminate any problem with predators that also ingest leaf tissue. In addition, a water-saturated cotton ball was provided on the bottom of each cup to maintain humidity. FAW were changed daily and C. maculata were checked twice per day (9 a.m. and 9 p.m.), and the following parameters were recorded: survival and developmental time of larvae and pupae. In addition, newly emerged $C$. maculata adults were weighed. The experiment was initiated with $50 \mathrm{C}$. maculata larvae for each treatment. For assessing fecundity, 10 pairs of newly emerged $C$. maculata adults from both treatments were kept in individual Petri dishes (diameter $9 \mathrm{~cm}$ ) and allowed to mate. Adults were fed shrimp eggs and agar solution for 20 days, according to the procedures of Li et al. (2011a). Eggs of C. maculata were removed and recorded daily. To investigate egghatching rates, 30 egg masses from both treatments were randomly selected and put into individual Petri dishes (diameter $9 \mathrm{~cm}$ ) and monitored until eggs hatched.

The offspring (F2 of $C$. maculata) underwent another generation of testing, as described above.

\section{Cry1F residue in insects}

Another 100 1st instar C. maculata for each treatment were reared as described for the tri-trophic bioassay. Three samples (6-10 insects as one replicate) from each treatment were collected when $C$. maculata reached the 2nd instar, 3rd instar, 4th instar, pupa and early adult stage. Newly hatched FAW, which were fed Cry1F maize (V5) or control maize (V5), were also sampled (10 larvae as one replicate, three replications) at 24,48 and $72 \mathrm{~h}$. The Cry1F toxin concentrations and bioactivities in the samples were determined by ELISA and bioactivity bioassays using P. xylostella larvae (see below).

\section{ELISA measurement}

The concentrations of Cry1F in maize leaves and insects were measured by ELISA using Cry1F detection kits from Agdia (Elkhart, IN). Prior to analysis, all 
insects were washed with PBST buffer four times to remove any $\mathrm{Bt}$ toxin from the surface. Maize leaf samples were diluted at a rate of 1:20 (mg sample: $\mu 1$ PBST buffer) and fully ground by mortar and pestle. Insect samples were diluted at a rate of at least 1:10 (mg sample: $\mu$ PBST buffer) in $1.5 \mathrm{ml}$ centrifuge tubes, and ground by hand using a plastic pestle. ELISA was performed according to the manufacturer's instructions.

Bioactivity of Cry1F after ingestion by FAW and C. maculata

Samples of Cry1F maize (V5) leaves, non-Bt maize (V5) leaves, FAW fed on Cry1F maize for $48 \mathrm{~h}$, FAW fed on non-Bt maize for $48 \mathrm{~h}, 4$ th instar C. maculata fed on Cry1F maize-fed FAW and 4th instar C. maculata fed on non-Bt maize-fed FAW were used in this experiment. Cry1F containing samples were diluted to $4 \mathrm{ng}$ Cry $1 \mathrm{~F} / \mathrm{ml}$. Corresponding control samples were diluted at a similar rate. Bond-spreader sticker (Loveland Industry, Loveland CO) was added at $0.1 \%$ to each sample solution before being applied to cabbage leaf disks (diameter $3 \mathrm{~cm}$ ). Ten 2nd instar Cry1F-susceptive $P$. xylostella (strain G88) were placed on each of the leaf disks inside $30 \mathrm{ml}$ Cometware $^{\mathrm{TM}}$ plastic cups (WNA, Covington, KY) with 5 replicates per treatment. Larval mortality was checked after $72 \mathrm{~h}$ at $27 \pm 1^{\circ} \mathrm{C}$.

Statistical analyses

Data on ELISA and toxicity of Cry1F in plant tissue and insects were analyzed using one-way analysis of variance (ANOVA) and Tukey's multiple-range test. Survival analysis of FAW fed on Bt maize or non-
Bt maize was conducted using the Wilcoxon test for homogeneity. Data on life table parameters of FAW and C. maculata were analyzed using Student's $t$ test. Data on bioactivity of Cry1F were analyzed using one-way ANOVA and Tukey's multiple comparison test. Before analysis, all percentage data were arcsine of square root transformed, as necessary, but untransformed means are presented. All statistical calculations were performed with SAS version 9.1 package (SAS Institute 2001). For all tests, $\alpha=0.05$.

\section{Results}

Cry $1 \mathrm{~F}$ in Bt maize, FAW and C. maculata

The Cry1F maize variety used in the present study was shown to express Cry $1 \mathrm{~F}$ at levels ranging from 2.38 to $4.33 \mu \mathrm{g} / \mathrm{g}$ fresh weight (FW) (Table 1). The Cry1F maize variety reached the highest Cry1F expression level at V3 stage. Cry1F expression level decreased as maize aged.

Cry1F residue in FAW was at levels ranging from 95.9 to $211.8 \mathrm{ng} / \mathrm{g}$ FW (Table 1). The Cry1F concentrations in FAW that fed on Cry $1 \mathrm{~F}$ maize for 48 and $72 \mathrm{~h}$ were significantly higher than those in FAW that fed on Cry1F maize for $24 \mathrm{~h}$.

The Cry1F concentrations in C. maculata larvae were 3-10 times lower than those in FAW, ranging from 20.3 to $32.2 \mathrm{ng} / \mathrm{g} \mathrm{FW}$ (Table 1). Cry1F in C. maculata pupae was $9.3 \mathrm{ng} / \mathrm{g}$. No Cry1F was detected in newly emerged $C$. maculata adults. As expected, no Cry $1 \mathrm{~F}$ was detected in non-Bt maize or FAW fed on non-Bt maize and C. maculata fed on non-Bt maize-fed FAW.

Table 1 Cry1F concentration in Cry1F maize leaves, S. frugiperda (FAW) and Coleomagilla maculata $(\mathrm{n}=3)$

\begin{tabular}{|c|c|c|c|c|c|}
\hline \multicolumn{2}{|c|}{ Cry1F maize $(\mu \mathrm{g} / \mathrm{g} F W)$} & \multicolumn{2}{|c|}{ FAW (ng/g FW) } & \multicolumn{2}{|c|}{ C. maculata (ng/g FW) } \\
\hline V1 & $3.98 \pm 0.052 \mathrm{ab}$ & Fed for $24 \mathrm{~h}$ & $95.9 \pm 9.03 \mathrm{~b}$ & 2nd instar & $20.3 \pm 2.36 \mathrm{a}$ \\
\hline V3 & $4.33 \pm 0.298 \mathrm{a}$ & Fed for $48 \mathrm{~h}$ & $211.8 \pm 19.12 \mathrm{a}$ & 3rd instar & $20.9 \pm 3.36 \mathrm{a}$ \\
\hline V5 & $3.21 \pm 0.233 \mathrm{ab}$ & Fed for $72 \mathrm{~h}$ & $176.3 \pm 9.58 \mathrm{a}$ & 4th instar & $32.2 \pm 11.44 \mathrm{a}$ \\
\hline V7 & $2.64 \pm 0.553 \mathrm{ab}$ & & & Pupae & $9.3 \pm 1.35 \mathrm{a}$ \\
\hline V10 & $2.47 \pm 0.531 \mathrm{~b}$ & & & Adults & Not detectable \\
\hline VT & $2.38 \pm 0.257 \mathrm{~b}$ & & & & \\
\hline
\end{tabular}

Mean $( \pm \mathrm{SE})$ followed by different letters in the same column are significantly different (One-way ANOVA, $P<0.05$ )

$F W$ fresh weight 
Table 2 Impact of Cry1F maize on life table parameters of Cry1F-resistant S. frugiperda

\begin{tabular}{|c|c|c|}
\hline Parameters & Cry1F maize & Non-Bt isoline \\
\hline Survival (\%) & $96.67 \mathrm{a}$ & $93.33 \mathrm{a}$ \\
\hline \multicolumn{3}{|c|}{ Development time (days) } \\
\hline Larva-pupation & $17.5 \pm 0.13(29) \mathrm{a}$ & $16.9 \pm 0.18(28) b$ \\
\hline Pupal stage & $9.4 \pm 0.24(29) \mathrm{a}$ & $9.7 \pm 0.25(28) \mathrm{a}$ \\
\hline Larva-adult & $26.9 \pm 0.35(29) \mathrm{a}$ & $26.5 \pm 0.40(28) \mathrm{a}$ \\
\hline $\begin{array}{l}\text { Adult longevity } \\
\text { (days) }\end{array}$ & $4.6 \pm 0.17(29) \mathrm{a}$ & $4.7 \pm 0.18(28) \mathrm{a}$ \\
\hline $\begin{array}{l}\text { Pupal weight } \\
\text { (mg) }\end{array}$ & $223.2 \pm 4.3(29) \mathrm{a}$ & $221.3 \pm 3.6(28) \mathrm{a}$ \\
\hline
\end{tabular}

Mean $( \pm$ SE) followed by different letters in the same row are significantly different (Survival: Wilcoxon test, $P<0.05$; other parameters: Student's $t$ test, $P<0.05$ )

n, sample size

\section{Bioassay with FAW}

There were no significant differences in survival of the FAW larvae when fed either Cry1F maize or control maize, and in both cases survival was $>93 \%$ $\left(\chi^{2}=0.0014, d f=1, P=0.97\right)$ (Table 2). A slight, but statistically significant difference, in total development time from larva to pupa occurred, but this amounted to only 0.6 days out of 17 days total $(t=2.5468, d f=55, P=0.0137)$. There were no significant differences in any of the other life table parameters (Table 2).

Tri-trophic bioassay with C. maculata

After feeding on Bt maize-fed and non-Bt maize-fed FAW, C. maculata had three molts before they reached the pupal stage (Table 3). Adults emerged from pupae after 2.5-3.5 days pupation. There were no significant differences detected for any life table parameters of $C$. maculata between the Cry $1 \mathrm{~F}$ maize treatment and control maize treatment.

Similar results were found for the second generation (Table 4). No significant differences were found for any life table parameters between the Cry $1 \mathrm{~F}$ maize treatment and control maize treatment.

\section{Bioactivity of Cry1F after ingestion by FAW} and C. maculata

Extracts from Cry1F maize leaves and Cry1F maizefed FAW larvae were toxic to susceptible P. xylostella
Table 3 Tri-trophic effects on life table parameters of C. maculata when fed Cry1F-resistant $S$. frugiperda larvae that were reared on Cry $1 \mathrm{~F}$ or non-Bt isoline maize leaves

\begin{tabular}{lrr}
\hline Parameters & \multicolumn{1}{l}{ Cry1F maize } & \multicolumn{1}{l}{ Non-Bt isoline } \\
\hline Development time (days) & \\
1st instar & $3.16 \pm 0.11(31) \mathrm{a}$ & $3.23 \pm 0.14(28) \mathrm{a}$ \\
2nd instar & $2.81 \pm 0.14(29) \mathrm{a}$ & $2.98 \pm 0.12(28) \mathrm{a}$ \\
3rd instar & $3.32 \pm 0.13(28) \mathrm{a}$ & $2.98 \pm 0.14(28) \mathrm{a}$ \\
4th instar & $5.00 \pm 0.12(28) \mathrm{a}$ & $4.98 \pm 0.11(28) \mathrm{a}$ \\
Pupal stage & $3.18 \pm 0.05(28) \mathrm{a}$ & $3.19 \pm 0.04(28) \mathrm{a}$ \\
Larvae-adults & $17.43 \pm 0.24(28) \mathrm{a}$ & $17.38 \pm 0.13(28) \mathrm{a}$ \\
Male fresh & $7.83 \pm 0.20(15) \mathrm{a}$ & $7.89 \pm 0.32(13) \mathrm{a}$ \\
weight (mg) & & \\
$\begin{array}{l}\text { Female fresh } \\
\text { weight (mg) }\end{array}$ & $10.12 \pm 0.30(13) \mathrm{a}$ & $9.86 \pm 0.20(15) \mathrm{a}$ \\
Total fecundity & $77.7 \pm 16.2(10) \mathrm{a}$ & $70.9 \pm 17.0(10) \mathrm{a}$ \\
$\begin{array}{l}\text { Egg hatching } \\
\text { rate (\%) }\end{array}$ & $63.9 \pm 3.76(30) \mathrm{a}$ & $66.7 \pm 2.77(30) \mathrm{a}$ \\
\hline
\end{tabular}

Mean $( \pm$ SE) followed by different letters in the same row are significantly different (Student's $t$ test, $P<0.05$ )

n, sample size

(Table 5). This indicates that C. maculata that fed on Cry1F maize-fed FAW were exposed to active Cry1F. However, Cry $1 \mathrm{~F}$ in $C$. maculata showed no toxicity to susceptible $P$. xylostella.

\section{Discussion}

Bt crops, as one important integrated pest management (IPM) component, have reduced traditional insecticides use, providing benefits for the environment, economy and human health (Shelton et al. 2002; Brookes and Barfoot 2009; Naranjo 2011). However, there is a concern as to whether $\mathrm{Bt}$ crops are compatible with another IPM component, biological control. Biological control of insect pest through predators and parasitoids is an important element of IPM and so many studies have focused on potential effects of Bt crops on natural enemies (Romeis et al. 2008; Wolfenbarger et al. 2008; Naranjo 2009). Although the majority of studies have shown no negative effects of Bt crops on natural enemies, some laboratory studies have mistakenly measured the effects of prey or host quality and not the direct effect of Bt toxicity, e.g. Lövei et al. (2009). These effects have erroneously been interpreted as direct toxic 
Table 4 Tri-trophic effects of Cry1F maize on the progeny of C. maculata fed Cry1F-resistant $S$. frugiperda larvae that were reared on Cry $1 \mathrm{~F}$ or non-Bt isoline maize leaves

\begin{tabular}{lcr}
\hline Parameters & \multicolumn{1}{l}{ Cry1F maize } & \multicolumn{1}{l}{ Non-Bt isoline } \\
\hline Development time (days) & \\
1st instar & $3.19 \pm 0.17(31) \mathrm{a}$ & $3.25 \pm 0.17(32) \mathrm{a}$ \\
2nd instar & $2.79 \pm 0.16(29) \mathrm{a}$ & $2.95 \pm 0.20(29) \mathrm{a}$ \\
3rd instar & $3.29 \pm 0.14(29) \mathrm{a}$ & $2.93 \pm 0.20(28) \mathrm{a}$ \\
4th instar & $5.16 \pm 0.12(29) \mathrm{a}$ & $5.11 \pm 0.22(28) \mathrm{a}$ \\
Pupal stage & $3.07 \pm 0.05(29) \mathrm{a}$ & $3.23 \pm 0.05(28) \mathrm{a}$ \\
Larvae-adults & $17.40 \pm 0.20(29) \mathrm{a}$ & $17.30 \pm 0.34(28) \mathrm{a}$ \\
$\begin{array}{l}\text { Male fresh } \\
\text { weight (mg) }\end{array}$ & $8.18 \pm 0.12(16) \mathrm{a}$ & $7.99 \pm 0.19(16) \mathrm{a}$ \\
Female fresh & $9.87 \pm 0.15(13) \mathrm{a}$ & $9.95 \pm 0.24(13) \mathrm{a}$ \\
$\quad$ weight (mg) & & \\
Total fecundity & $74.0 \pm 13.3(10) \mathrm{a}$ & $58.5 \pm 15.0(10) \mathrm{a}$ \\
$\begin{array}{l}\text { Egg hatching } \\
\text { rate }(\%)\end{array}$ & $70.4 \pm 5.66(30) \mathrm{a}$ & $73.0 \pm 3.65(30) \mathrm{a}$ \\
\hline
\end{tabular}

Mean $( \pm$ SE) followed by different letters in the same row are significantly different (Student's $t$ test, $P<0.05$ )

$\mathrm{n}$, sample size

effects of the Cry protein (Shelton et al. 2009a, b). Using Bt-resistant herbivores has been suggested as a way of overcoming the potential effects of prey/hostquality in an assessment of the effects of plantexpressed insecticidal proteins on natural enemies (Romeis et al. 2011).

A Bt-resistant strain eliminates effects of prey or host quality and also contains a higher concentration of Bt proteins when compared with a susceptible strain (Lawo et al. 2010). In this study, we used Cry1Fresistant FAW, the first herbivore to evolve resistance to a Bt plant in the field, as the carrier of Cry1F. Although others have used $\mathrm{Bt}$ resistant strains to overcome host quality effects (e.g. Li et al. 2011b), no other studies have used strains that have evolved resistance to a Bt plant under field conditions, thus adding another level of assurance. Our results showed that FAW feeding on Cry $1 \mathrm{~F}$ maize only contained $3-6 \%$ of the Cry $1 \mathrm{~F}$ proteins in the plant, and that there were no significant differences in survivorship or the development time from larva to adult stage compared to when they fed on non-Bt maize. This is consistent with the data in Storer et al. (2010) that indicated the resistant strain is unaffected by high concentrations of Cry1F. The bioactivity assays confirmed that Cry1F protein was still biologically active even after ingestion by FAW. Thus, with our Cry1F maize/ Cry1F-resistant FAW/natural enemy ( $C$. maculata) tri-trophic bioassay system, we were able to overcome any host quality effect and evaluate the direct potential toxicity of Cry $1 \mathrm{~F}$ to $C$. maculata through a biologically realistic pathway.

Our results demonstrated Cry1F maize had no significant impact on developmental time, adults weight and fecundity of $C$. maculata. This is consistent with another study that evaluated the potential effects of Bt crops on ladybird beetles. Lundgren and Wiedenmann (2002) and Duan et al. (2002) demonstrated Cry3Bb1 did not impact any of the fitness parameters (including the duration of larval and pupal stages, pupal weight, adult mobility, adult survivorship, and female fecundity) of $C$. maculata when the ladybird beetles were fed with Bt-maize pollen. Larval survival and development, adult survival, and adult dry weight did not differ for ladybird beetles, Stethorus punctillum (Weise) (Coleoptera: Coccinellidae), fed with spider mites, Tetranychus urticae (Koch) (Acari: Tetranychidae), reared on Cry3Bb1 maize or non-Bt maize ( $\mathrm{Li}$ and Romeis 2010). Similarly, C. maculata survival, development time, adult weight and fecundity were not different when they were fed with resistant cabbage looper, Trichoplusia $n i$ (Hübner) (Lepidoptera: Noctuidae), larvae reared on either Bt cotton (expressing Cry1 Ac and Cry2Ab) or control cotton (Li et al. 2011b).

Cry1F maize leaves used in this study contained 2.7-3.4 $\mu \mathrm{g} / \mathrm{g}$ FW Cry $1 \mathrm{~F}$ protein. Similar results of Cry $1 \mathrm{~F}$ protein levels in $\mathrm{Bt}$ maize leaves were reported in two other Cry1F maize varieties Herculex ${ }^{\circledR}$ I $\left(111 \mathrm{ng} / \mathrm{g}\right.$ total protein) and Herculex ${ }^{\mathrm{TM}}$ I (10-23 $\mathrm{ng} / \mathrm{mg}$ dry weight) (US Environmental Protection Agency Office of Pesticide Programs 2005; DuPont 2011). Our ELISA measurement demonstrated that only $10-20 \%$ of the Cry $1 \mathrm{~F}$ found in FAW larvae was detected in C. maculata larvae (Table 1). Similar dilution effects have been reported in other tritrophic studies. For example, when $C$. maculata was fed with Cry1Ac and Cry2Ab-expressing Bt cotton-fed cabbage looper, T. $n i, \mathrm{Bt}$ protein levels in predators were 21 times lower for Cry2Ab and 6 times lower for Cry1Ac compared to the concentrations in the prey ( $\mathrm{Li}$ et al. 2011b). Similarly, when spider mites, T. urticae, fed with Cry3Bb1 maize were used as prey, the $\mathrm{Cry} 3 \mathrm{Bb} 1$ protein level in larvae and adults of ladybird beetles, S. punctillum were 6 and 20 times lower than 
Table 5 Bioactivity of Cry1F residue from $S$. frugiperda and C. maculata to Cry1F-susceptible Plutella xylostella larvae

\begin{tabular}{lc}
\hline Treatment & $\begin{array}{l}\text { Mortality } \% \\
\text { (Means } \pm \text { SE) }\end{array}$ \\
\hline Cry1F maize leaf & $66.0 \pm 9.27 \mathrm{a}$ \\
Non-Bt maize leaf & $10.0 \pm 3.16 \mathrm{~b}$ \\
FAW reared on Cry1F maize leaf for $48 \mathrm{~h}$ & $48.0 \pm 4.90 \mathrm{a}$ \\
FAW reared on non-Bt maize leaf for $48 \mathrm{~h}$ & $6.0 \pm 4.0 \mathrm{~b}$ \\
4th instar $C$. maculata fed on Cry1F maize- & $24.0 \pm 2.45 \mathrm{~b}$ \\
$\quad$ fed FAW & \\
4th instar $C$. maculata fed on non-Bt maize- & $18.0 \pm 3.74 \mathrm{~b}$ \\
$\quad$ fed FAW & \\
d $\mathrm{H}_{2} \mathrm{O}$ (Control) & $8.0 \pm 3.74 \mathrm{~b}$ \\
\hline
\end{tabular}

A total of 50 susceptible $P$. xylostella larvae were used in each treatment with 5 replications (10 larvae/replication). Means $( \pm \mathrm{SE})$ followed by different letters are significantly different (One-way ANOVA, $P<0.05$ )

Bt protein concentrations measured in spider mites, respectively ( $\mathrm{Li}$ and Romeis 2010). First and second instars of Adalia bipunctata (Linnaeus) contained 7-12 times lower levels of Bt proteins compared to the prey $T$. urticae that fed on Cry1Ac or Cry3Bb1expressing Bt maize (Alvarez-Alfageme et al. 2011). This indicates that Bt protein did not bioaccumulate and biomagnify when transferred from prey to predator. Furthermore, bioactivity of Cry1F tests showed Cry1F protein in $C$. maculata was not bioactive (Table 5). We assume Cry1F decomposed in this predator to protein fragments that had no bioactivity.

To date, most studies have been conducted to assess the potential effects of Bt on NTOs for only a single generation. However, there has been some concern about whether adverse effects might only be manifested in subsequent generations. Our study indicated Bt maize did not harm $C$. maculata even when they were exposed to Cry $1 \mathrm{~F}$ for two generations. This helps support the 3-year field observation that Cry1F maize did not impact the abundance of ladybird beetles (including eggs, egg clutches, larvae and adults) (Higgins et al. 2009).

In conclusion, our studies with Cry 1F-resistant FAW, the first insect to have evolved resistance to a $\mathrm{Bt}$ plant in the field, allowed us to eliminate any potential prey-quality effects when examining the potential effect of Cry1F in a tri-trophic test with an important predator of FAW, C. maculata. Our studies demonstrated that Cry1F did not affect important fitness parameters of $C$. maculata and that Cry $1 \mathrm{~F}$ protein did not accumulate but rather decomposed when transferred during trophic interactions. These results, together with other published literature, demonstrate no adverse effects of Cry1F, and thus Cry1F-expressing Bt maize, on C. maculata.

Open Access This article is distributed under the terms of the Creative Commons Attribution License which permits any use, distribution, and reproduction in any medium, provided the original author(s) and the source are credited.

\section{References}

Alvarez-Alfageme F, Bigler F, Romeis J (2011) Laboratory toxicity studies demonstrate no adverse effects of Cry1 Ab and Cry3Bb1 to larvae of Adalia bipunctata (Coleoptera: Coccinellidae): the importance of study design. Transgenic Res 20:467-479

Brookes G, Barfoot P (2009) Global impact of biotech crops: Socio-economic and environmental effects 1996-2007. Outlooks Pest Manag 20:258-264

Buntin GD (2008) Corn expressing Cry1ab or Cry1f endotoxin for fall armyworm and corn earworm (Lepidoptera: Noctuidae) management in field corn for grain Production. Florida Entomologist 91:523-530

Buntin GD, All JN, Lee RD, Wilson DM (2004) Plant-incorporated Bacillus thuringiensis resistance for control of fall armyworm and corn earworm (Lepidoptera: Noctuidae) in corn. J Econ Entomol 97:1603-1611

Duan JJ, Head G, McKee MJ et al (2002) Evaluation of dietary effects of transgenic corn pollen expressing Cry3Bb1 protein on a non-target ladybird beetle, Coleomegilla maculata. Entomol Exp Appl 104:271-280

DuPont (2011) Herculex ${ }^{\circledR}$ I detailed safety assessment. http:// www2.dupont.com/Biotechnology/en_US/products/plant_ biotech_products/herculex/safety2.html\#one. Accessed 5 December 2011

FAOSTAT (2009) Food and agriculture organization of the United Nations. The statistics division. http://faostat.fao. org/ (accessed 18 September 2011)

Hellmich RL, Albajes R, Bergvinson D et al (2008) The present and future role of insect-resistant genetically modified maize in IPM. In: Romeis J, Shelton AM, Kennedy GG (eds) Integration of insect-resistant, genetically modified crops within IPM programs. Springer, Dordrecht, pp 119-158

Higgins LS, Babcock J, Neese P et al (2009) Three-year field monitoring of Cry1F, event DAS- $\varnothing 15 \varnothing 7-1$, maize hybrids for nontarget Arthropod effects. Environ Entomol 38: 281-292

Institute SAS (2001) PROC user's manual, 6th edn. Cary, NC, SAS Institute

James C (2010) Global Status of Commercialized Biotech/GM Crops: 2010. ISAAA Brief No. 42. ISAAA, Ithaca, NY

Kennedy GG (2008) Integration of insect-resistant genetically modified crops within IPM programs. In: Romeis J, Shelton AM, Kennedy GG (eds) Integration of insect-resistant, genetically modified crops within IPM programs. Springer, Dordrecht, pp 1-26 
Lawo NC, Wackers FL, Romeis J (2010) Characterizing indirect prey-quality mediated effects of a Bt crop on predatory larvae of the green lacewing, Chrysoperla camea. J Insect Physiol 56:1702-1710

Li YH, Romeis J (2010) Bt maize expressing Cry3Bb1 does not harm the spider mite, Tetranychus urticae, or its ladybird beetle predator, Stethorus punctillum. Biol Control 53: 337-344

Li YH, Ostrem J, Romeis J et al (2011a) Development of a Tier1 assay for assessing the toxicity of insecticidal substances against Coleomegilla maculata. Environ Entomol 40: 496-502

Li YH, Romeis J, Wang P, Peng YF, Shelton AM (2011b) A comprehensive assessment of the effects of $\mathrm{Bt}$ cotton on Coleomegilla maculata demonstrates no detrimental effects by Cry1Ac and Cry2A. PLoS ONE 6:e22185

Lövei GL, Andow DA, Arpaia S (2009) Transgenic insecticidal crops and natural enemies: a detailed review of laboratory studies. Environ Entomol 38:293-306

Luginbill P (1928) The fall armyworm. USDA Technical Bulletin No. 34

Lundgren JG, Wiedenmann RN (2002) Coleopteran-specific $\mathrm{Cry} 3 \mathrm{Bb}$ toxin from transgenic corn pollen does not affect the fitness of a nontarget species, Coleomegilla maculata DeGeer (Coleoptera : Coccinellidae). Environ Entomol 31: 1213-1218

Lundgren JG, Wiedenmann RN (2005) Tritrophic interactions among Bt (Cry3Bb1) corn, aphid prey, and the predator Coleomegilla maculata (Coleoptera : Coccinellidae). Environ Entomol 34:1621-1625

Marvier M, McCreedy C, Regetz J, Kareiva P (2007) A metaanalysis of effects of Bt cotton and maize on nontarget invertebrates. Science 316:1475-1477

Matten SR, Head GP, Quemada HD (2008) How government regulations can help or hinder the integration of $\mathrm{Bt}$ crops within IPM programs. In: Romeis J, Shelton AM, Kennedy GG (eds) Integration of insect-resistant, genetically modified crops within IPM programs. Springer, Dordrecht, pp $27-40$

Naranjo SE (2009) Impacts of Bt crops on non-target invertebrates and insecticide use pattern. CAB Reviews: Perspectives in Agriculture, Veterinary Science, Nutrition and Natural Resources 11: http://www.cabi.org/cabreview

Naranjo SE (2011) Impacts of Bt transgenic cotton on integrated pest management. Journal of Agricultural and Food Chemistry 59:5842-5851

Pilcher CD, Obrycki JJ, Rice ME, Lewis LC (1997) Preimaginal development, survival, and field abundance of insect predators on transgenic Bacillus thuringiensis corn. Environ Entomol 26:446-454

Ritchie SW, Hanway JJ, Benson GO (1992) How a corn plant develops. Iowa State University, Cooperative Extension Service, special report 48. Ames, IA
Romeis J, Meissle M, Bigler F (2006) Transgenic crops expressing Bacillus thuringiensis toxins and biological control. Nat Biotechnol 24:63-71

Romeis J, Bartsch D, Bigler F et al (2008) Assessment of risk of insect-resistant transgenic crops to nontarget arthropods. Nat Biotechnol 26:203-208

Romeis J, Hellmich RL, Candolfi MP et al (2011) Recommendations for the design of laboratory studies on non-target arthropods for risk assessment of genetically engineered plants. Transgenic Res 20:1-22

Shelton AM, Cooley RJ, Kroening MK, Wilsey WT, Eigenbrode SD (1991) Comparative analysis of two rearing procedures for diamondback moth, Plutella xylostella (Lepidoptera: Plutellidae). Journal of Entomological Science 26:17-26

Shelton AM, Zhao JZ, Roush RT (2002) Economic, ecological, food safety, and social consequences of the deployment of Bt transgenic plants. Annu Rev Entomol 47:845-881

Shelton AM, Naranjo SE, Romeis J et al (2009a) Setting the record straight: a rebuttal to an erroneous analysis on transgenic insecticidal crops and natural enemies. Transgenic Res 18:317-322

Shelton AM, Naranjo SE, Romeis J et al (2009b) Appropriate analytical methods are necessary to assess nontarget effects of insecticidal proteins in GM crops through meta-analysis (Response to Andow et al. 2009). Environ Entomol 38: 1533-1538

Siebert MW, Tindall KV, Leonard BR, Van Duyn JW, Babcock JM (2008) Evaluation of corn hybrids expressing Cry1F (Herculex $\mathrm{I}^{\circledR}$ insect protection) against fall armyworm (Lepidoptera : Noctuidae) in the southern United States. Journal of Entomological Science 43:41-51

Sparks AN (1979) A review of the biology of the fall armyworm. Fla Entomol 62:82-87

Storer NP, Babcock JM, Schlenz M et al (2010) Discovery and characterization of field resistance to Bt maize: Spodoptera frugiperda (Lepidoptera: Noctuidae) in Puerto Rico. J Econ Entomol 103:1031-1038

Tabashnik BE, Van Rensburg JBJ, Carriere Y (2009) Fieldevolved insect resistance to Bt crops: definition, theory, and data. J Econ Entomol 102:2011-2025

US Environmental Protection Agency Office of Pesticide Programs (2005) Biopesticide registration action document Bacillus thuringiensis Cry1F corn. http://www.epa.gov/ oppbppd1/biopesticides/ingredients/tech_docs/brad_0064 81.pdf Accessed 5 December 2011

Wolfenbarger LL, Naranjo SE, Lundgren JG, Bitzer RJ, Watrud LS (2008) Bt crops effects on functional guilds of nontarget arthropods: a meta-analysis. PLoS ONE 3:e2118. doi:10.1371/journal.pone.0002118 